\title{
The Turn to Problematization: Political Implications of Contrasting Interpretive and Poststructural Adaptations
}

\author{
Carol Bacchi \\ The Department of Politics \& International Studies, University of Adelaide, Adelaide, Australia \\ Email: carol.bacchi@adelaide.edu.au
}

Received 5 November 2014; revised 2 December 2014; accepted 22 December 2014

Copyright (C) 2015 by author and Scientific Research Publishing Inc.

This work is licensed under the Creative Commons Attribution International License (CC BY). http://creativecommons.org/licenses/by/4.0/

(c) (i) Open Access

\begin{abstract}
The purpose of this paper is to introduce and elaborate the varied meanings of problematization in contemporary policy theory. The primary focus is on the different meanings and uses of the term in interpretivism and in Foucault-influenced poststructuralism. The paper argues that interpretive/argumentative adaptations direct attention primarily to how policy makers/workers develop problematizations (ways of understanding a problem) while Foucault-influenced poststructuralists critically scrutinize problematizations (the ways in which "problems" are produced and represented) in governmental policies and practices. It concludes that Foucault-influenced adaptations provide a more substantive critique of extant social arrangements than interpretive approaches, which tend to be reformist in design and inclination.
\end{abstract}

Keywords

Problematization, Poststructuralism, Policy, Foucault, Interpretivism, Problem Representations

\section{Introduction}

It seems fair to say that the term problematization has taken the western theoretical world by storm. Alvesson \& Sandberg (2013: p. 116) identify "various 'problematization turns' (for example, interpretive, political, linguistic, constructionist and postmodernist)". Here are a few of the many theorists for whom problematization is an important concept in their analytic repertoire. They are listed in alphabetical order: Mats Alvesson, Carol Bacchi, Michel Callon, Hal Colebatch, Mitchell Dean, Gilles Deleuze, Norman Fairclough, Frank Fischer, Paulo Freire, Michel Foucault, Jason Glynos, Susan Goodwin, Steven Griggs, Barry Hindess, Robert Hoppe, David Howarth, Colin Koopman, Peter Miller, Michael Meyer, Uma Narayan, Thomas Osborne, Paul Rabinow, Malin Rönnblom, 
Nikolas Rose, Jörgen Sandberg and Nick Turnbull.

These theorists include philosophers and political theorists. Some are associated with specific schools of thought or specific analytic traditions, with overlaps in perspective. For example, Michel Callon is associated with Actor-Network theory. Paul Rabinow and Colin Koopman are associated with the Anthropology of the Contemporary Research Collaboratory (ARC) and the Critical Genealogies Collaboratory. Miller, Rose, Osborne, Hindess and Dean all work with the concept of "governmentality". Fairclough is best known for his development of Critical Discourse Analysis (CDA). Hoppe, Turnbull and Fischer align themselves with an interpretive approach to policy analysis. Alvesson and Sandberg are management theorists. Turnbull and Meyer are philosophers. Glynos, Griggs and Howarth are associated with the Essex School of Discourse Analysis and Political Discourse Theory, influenced by Laclau. They describe themselves as poststructuralists and locate their stance "alongside other types of interpretive policy analysis" (Howarth \& Griggs, 2012: p. 306). Goodwin, Rönnblom and Bacchi, whose work is influenced by Foucault, also call themselves poststructuralists but do not associate themselves with interpretivism ${ }^{1}$.

It is difficult for readers who encounter the terms "problematize" or "problematization" to make sense of the varied adaptations associated with these numerous contrasting perspectives. This article attempts to provide guidance to the specific usages within interpretive and Foucault-influenced poststructural analytical approaches. Where relevant, comparisons will be drawn with other theoretical positions that offer "problematization" as a key concept.

To be clear from the outset, there is no claim in this paper that the term "problematization" has a single correct meaning and/or ought to be used in only one way. Borrowing from Tanesini (1994: p. 207), concepts are not descriptive of anything. They have no fixed meaning. Rather, they are "proposals about how we ought to proceed from here". Therefore, they can be defined to certain purposes and redefined to other purposes. Their meaning is contested. Hence it should be no surprise to discover that researchers give the term "problematization" a meaning that fits their analytic paradigm and/or political vision. In this situation, the task becomes understanding particular usages of the concept and their purposes, as undertaken below. The argument is developed that Foucault-influenced adaptations of problematization provide a more substantive critique of extant social arrangements than interpretive approaches.

\section{A Little Bit of Grammar}

At the risk of oversimplifying, the term "problematization" tends to be used either as a verb (i.e. to problematize) to describe what people (policy makers/workers, researchers) do, or what governments (broadly conceived) ${ }^{2}$ do, or as a noun (i.e. problematizations), generally to refer to the outcomes of problematizing. The verb form can be used in two ways: first, to describe a form of critical analysis; second, to refer to putting something forward, or designating something, as a "problem"- that is, to give a shape to something as a "problem"3.

The first verb meaning-problematizing as critical analysis-aligns with the colloquial use of the term to describe interrogating or questioning an issue. Researchers often use the term in this way to describe what they are doing in a particular text-i.e. problematizing a stance or an issue. However, when taken up in political theory, the term usually carries with it an understanding that the interrogating or questioning takes place at a level somewhat deeper than commonly assumed in everyday usage.

For example, some scholars have developed problematization as the basis of an analytic practice that takes place at the level of deep-seated presuppositions-necessary meanings antecedent to an argument-and assumptions about the world. Alvesson and Sandberg (2013: p. 71) put forward what they describe as "the problematization methodology", a way to critically assess assumptions and presuppositions in political and social theories. Bacchi's (1999; 2009) WPR (What's the Problem Represented to be?) approach to policy analysis offers a Foucault-influenced mode of problematization analysis that "consists in seeing on what type of assumptions, of fa-

\footnotetext{
${ }^{1}$ This last point illustrates that theorists use descriptors of analytic traditions in diverse ways. For the purposes of this paper the interpretive tradition is associated with those who are primarily concerned with the roles of social actors in political processes. Foucault-influenced poststructuralism is marked off from this tradition because of its commitment to questioning foundational conceptions of the political subject (Bacchi \& Rönnblom, 2014: p. 6). This point is elaborated later in the paper.

${ }^{2}$ This sense of broad governing practices is captured in the analytic concept, governmentality, which is discussed later in the paper.

${ }^{3}$ The use of inverted commas around "problems" indicates that the term is being problematized (i.e. put into question as part of a critical analytic practice-the first verb usage). In places where a specific theory appears to accept problems as real in some way, inverted commas are omitted.
} 
miliar notions, of established, unexamined ways of thinking the accepted practices are based" (Foucault, 1994 [1981]: p. 456). Webb (2014: p. 368) also offers a "policy problematization" approach that "seeks explanations about the ways thinking is practiced and produced".

The second verb use-to put something forward or constitute something as a "problem"-can refer to:

- How people (citizens, policy makers/workers, policy analysts) "frame" an issue, as in the interpretive tradition (Colebatch, Hoppe, \& Noordegraaf, 2010b: p. 231);

- How social scientists form a problem or an explanandum - that which is to be explained-as a "dialectical moment" in social science practice (Glynos \& Howarth, 2007: p. 34-38); or

- How governing (broadly conceived) involves problematizing, shaping issues as "problems", as in the Foucault-influenced poststructural tradition (Rose \& Miller, 1992: p. 181).

As a noun, problematizations generally refer to the outcomes of the processes of problematizing, be these the ways in which "problems" are framed or governmental problematizing processes. Analysts tend to refer, therefore, to the need to interrogate problematizations, in the plural, or to offer an adjectival adaptation, "problematized phenomena" (Glynos \& Howarth, 2007: p. 205). However, at times the noun form appears simply as the nominalization of the process of problematizing. So, you could talk about people engaging in problematization.

\section{Analytic Applications}

Analytic traditions do not divide along grammatical lines. That is, theorists across the analytic spectrum often use variations of the verb and the noun form in relation to each other. For example, Foucault uses problematization both as verb to describe his analytic strategy of "thinking problematically" and, as noun, to refer to the $o b$ jects for thought that emerge in historical problematizing practices, including governmental practices ("the forms of problematization themselves") (Foucault, 1986: p. 11-12; Bacchi, 2012; Koopman, 2013: p. 98). Poststructuralists in the Essex School use the verb form to identify the need to problematize, or interrogate, the different ways an issue has been problematized, or shaped as a "problem", by key social actors. They describe what social actors produce as problematizations (Glynos \& Howarth, 2007: p. 168) or as "problematized social phenomena" (Howarth, 2013: p. 267). Meanwhile, researchers in the interpretive tradition, who use problematize in the verb form to mean framing an issue as a "problem", use the noun form ("a problematization") to describe the outcome of this process.

Within these developments it is possible to identify two distinct analytic foci:

- A first, which encompasses those who broadly identify themselves as interpretivists, including the Essex School (see above), who emphasize the role of people, be they policy makers/workers or social scientists, as problematizing agents; and

- A second, Foucault-influenced perspective which directs attention to problematizations as the products of governmental practices.

To elaborate this distinction, in the interpretive tradition, the emphasis is on how people, mainly policy makers/workers, engage in problematizing, that is, how they offer an interpretation of a problem. The Essex School of poststructural theory shares this focus on the people engaged in problematizing (see above) but their interest is primarily in how social scientists construct a problem for analysis. In Foucault-influenced poststructuralism, by contrast, the analytic focus is on the conceptual underpinnings of identified governmental problematizations, "the forms of problematization themselves" (Foucault, 1986: p. 11-12), rather than on social actors as problematizing agents.

These contrasting forms of analysis reveal a basic ontological disagreement about the nature of political subjectivity. For interpretivists political subjects are seen as "agentic", that is, as sovereign or foundational subjects, who stand outside of and shape "reality". By contrast, in Foucault-influenced poststructuralism political subjects are constituted in discourses, understood as broad, socially produced forms of knowledge (Bacchi, 2009: p. 35). In the place of the "irreducible 'real person' who is 'made' (becomes a girl), or who 'makes' the world" (Jones, 1997: p. 262), Foucault-influenced poststructuralism proposes a non-essential "subjectivity which is precarious, contradictory and in process, constantly being reconstituted in discourse each time we think or speak" (Weedon, 1987: p. 32).

The Essex School of poststructuralism (Howarth, Norval, \& Stavrakakis, 2000: p. 18), influenced by Laclau, offers a complex understanding of political subjectivity. In line with a poststructuralist framework, it sees subjects as assuming "subject positions within a discursive structure". However, it also adopts an understanding of 
political subjectivity that "accounts for the agency of subjects". As a result, their political analysis, which necessitates acknowledging "a subject's contextualized self-interpretation” (Glynos \& Howarth, 2007: p. 15), aligns with interpretivism and stands at a distance from Foucauldian perspectives.

For Foucauldians, problematizations are ways of thinking that emerge from practices rather than from people as agents (Bacchi, 2012: p. 3). For example, in his study of "madness", Foucault (2009) argues that "madness" did not exist as an object for thought outside the practices that constitute it. He says that to see how "the mad" came to be thought of as a specific kind of "entity", we need to look at how they were treated (1969 in Eribon, 1991: 214) - how they were "set aside, excluded from society, interned, and treated". By examining these practices (what people did) you can see how "madness" was thought about or "problematized" (Bacchi, 2012), and that is what "madness" came to mean.

The same can be said to apply to the whole range of governed "objects", e.g. "delinquency", "out-of-wedlock births", "welfare", "population", "binge drinking", "problem gambling", and so on. These governmental categories, which we commonly think of as "entities", are produced through the very practices that create them as categories-e.g. practices of measurement and comparison. Moreover, these condensations of thinking and other practices shape and influence people in profound and uncharted ways. Attention, therefore, is directed away from an intentional, agentic human subject, as seen in interpretivism (above), to the myriad complex strategic relations that produce "subjects" in continual formation. Foucault (1986: p. 12-13) identifies "practical texts", such as regulations and decrees, as key sites where governmental "objects" and "subjects" are produced through problematization.

A task becomes considering how these different configurations of problematization-the interpretive focus on political agents who problematize, and the Foucauldian emphasis on the problematizations within policies that shape us as subjects - map onto political visions and political agendas, and what this might mean for those involved in policy development. At one level it might appear that the two positions simply align with different analytic tasks, with interpretivists primarily concerned with those involved in processes of policy formulation while Foucault-influenced poststructuralists assume, as their primary work, critical interrogation of the problematizations within existing policies. However, Foucault-influenced perspectives have significant implications for interpretivist goals and objectives, raising important questions about the form of critique they offer, as the paper proceeds to argue.

\section{Common Threads and Analytic Tensions}

As a generalization it is possible to say that the appearance of the term "problematization" in an analysis always signals a critical intent. One can assume that some species of challenge to the social and political status quo is envisaged and that, as a consequence, there are some shared premises among those who adopt the term. For example, both interpretivism and poststructuralism (Turnbull, 2008: p. 1; Glynos \& Howarth, 2007: p. 104) describe current social relations as contingent to suggest that things commonly taken for granted as simply "the way things are" could be quite different. Moreover, in both interpretivism and poststructuralism, there is a common antipathy to positivist methods of analysis (Howarth \& Griggs, 2012: p. 335), a tendency to prefer qualitative over quantitative research ${ }^{4}$, and serious reservations about standard understandings of policy design as involving "merely cognitive or rational processes" (Hoppe, 2011: p. 56; see also Turnbull, 2008: p. 15).

In addition, researchers who adopt the terms "problematizing" and "problematization" indicate by so doing that they share a conviction that "problems" are more interesting than "solutions". At a basic level this stance suggests links with Meyer's philosophy of questioning, called "problematology", and described by Turnbull (2008: p. 10) as a "philosophy of problematisation". There is also shared disquiet about the current emphasis in policy circles on problem-solving and evidence-based policy, on the view that these approaches treat "problems" as fixed and readily identifiable (Glynos \& Howarth, 2007: p. 167). By contrast references to "problematization" signal that "problems" are considered to be forms of construction, though there are different interpretations of what social construction entails that parallel the earlier distinction between agentic (agency-focused) and antifoundational (anti-essentialist) perspectives.

Contrast can be drawn between constructivism, which sees the person as "actively engaged in the creation of

${ }^{4}$ The Essex School (2009: p. 6) argues that discourse analytic approaches select "different methods or techniques in the study of discourse, whether these are qualitative, quantitative, or some combination of the two". Specifically, they integrate Q Methodology into their repertoire of analytic methods. 
their own phenomenal [sense-perceptible] world", and social constructionism, which emphasizes the extent to which our understandings of the world are the product of social forces (Burr, 2003: p. 19-20). These two foci fit the two analytic tasks identified above, with interpretivists paying primary attention to how policy actors shape problematizations in ongoing policy processes while Foucault-influenced poststructuralists examine the deep-seated conceptual logics that underpin governmental problematizations in existing policies, problematizations which shape who we are.

Interpretivists in the main, therefore, are social constructivists (Hoppe, 2011: p. 59). Theorists in this tradition describe, as the "essential process", "the joint construction of problems as a condition for joint responses". "Participants in policy making" are encouraged to problematize (or form problems) in ways that will "create some common or shared understandings" (Hoppe, 2011: p. 50). The objective is to direct attention to "the development of shared problematization which frames and justifies collective action" (Colebatch, Hoppe, \& Noordegraaf, 2010b: p. 236; emphasis added). By contrast Foucault-influenced poststructuralists do not engage the question of how people shape problematizations for instrumental ends. Rather, they focus on teasing out and interrogating the meanings within, and political implications of, existing forms of governmental problematization.

To tie this distinction back to meanings of problematization, in interpretive approaches, problematizations are considered to be competing understandings or interpretations of a problem which people (e.g. policy makers/ workers, citizens, researchers) put forward (Colebatch, Hoppe \& Noordegraaf, 2010b: p. 228), while in Foucault-influenced poststructuralism, problematizations are deeply ingrained ways of thinking (conceptual schema) that shape (to different degrees) who we are and how we live. It follows that interpretivists are primarily interested in the people engaged in problematizing (giving a shape to a problem) while, in the Foucault-influenced poststructural tradition, the mode of analysis focuses primarily on studying problematizations (the ways in which "problems" are produced and represented).

Put in other words, interpretivists direct attention to how people make meaning together (Colebatch, Hoppe, \& Noordegraaf, 2010b: p. 230; Hoppe, 2011: p. ix; Hoppe, 1999), whereas Foucault-influenced poststructuralists emphasize the need to scrutinize and question meanings that are in place. As signaled earlier, a basic ontological issue-how the political subject is imagined-separates the two traditions. Whereas interpretivists support a degree of rational agency (Colebatch, Hoppe, \& Noordegraaf, 2010a: p. 8; Turnbull, 2005: p. 275), Foucault-in- fluenced poststructuralists emphasize how subjects are constituted (or formed) within the very discourses (knowledges) that shape understandings of "problems". These contrasting views involve opposing conceptions of power with interpretivists developing a view of power as "power over", as the possession of "powerful elites" (Turnbull, 2005: p. 210), while Foucault-influenced poststructuralists describe power as productive, shaping subjects of particular sorts (Bacchi \& Rönnblom, 2014: p. 6). These differences play out in the kinds of political projects that are advanced, as elaborated in the following section.

\section{Problem Setting versus Governmentality}

As mentioned above, the use of the term "problematization" signals a critical intent. Indicating the critical agenda of interpretivism, Fischer \& Mandell (2012: p. 352) see a connection between Freire's (1970; 1973) concept of "problematization" and Schön's (1983) concept of "problem setting". Both interventions, say the authors, are intended to challenge hierarchical relations, in Freire between students and teachers, in Schön between practitioners and their clients. In problem setting, practitioners are invoked to initiate what Schön calls "a conversation with the situation" in order to define the problems that arise in specific situations. In other words practitioners are invited to problematize or form problems in particular ways that fit the circumstances.

Alongside "problem setting", interpretivists refer to "problem posing" (Turnbull, 2005: p. 177, 212), "problem sensing", "problem definition" (Colebatch, Hoppe, \& Noordegraaf, 2010b: p. 230), "questioning and problem finding", and "problem structuring" (Hoppe, 2011: p. 4-5). In each instance the emphasis is on some person or group of people engaging in problematizing, in the sense of shaping or framing a particular interpretation of a problem. Those involved in "problem structuring" are described as engaged in "processes of problematisation" (Hoppe, 2011: p. 23). The primary focus is on policy makers/workers and the challenges they face in developing shared understandings of a problem, described as a shared problematization (Colebatch, Hoppe, \& Noordegraaf, 2010: p. 236).

By contrast Foucault-influenced poststructural policy analysis examines how issues have been problematized in governmental practices in order to draw attention to possible gaps or silences in problematizations, and to the 
ways in which "subjects", "objects" and "problems" are constituted within them. The objective is not to develop a "shared problematization" but to facilitate critical interrogation of existing governmental problematizations. Government, in this view, involves the multiple agencies and groups (academics, professionals, experts) who contribute to societal administration—described as "the conduct of conduct" (Gordon, 1991: p. 2)-through the knowledges they produce ${ }^{5}$. Government is understood to be a "problematizing activity" (Rose \& Miller, 1992: p. 181), in which "policy cannot get to work without first problematizing its territory" (Osborne, 1997: p. 174). To intervene, it is argued, government, including but beyond the state, has to target something as a "problem" that needs "fixing". The critical task, in this account, becomes examining the ways in which specific issues are problematized.

The status of "a problem" marks a further distinction between interpretivism and poststructuralism, despite the apparent consensus that "problems" are constructions rather than fixed "entities" (see above). Those operating in the interpretive tradition agree with poststructuralists that it is necessary to challenge the notion of "problems" as "the pre-existing reason for the institution of a policy process" (Colebatch, Hoppe, \& Noordegraaf, 2010b: p. 239). Yet there remains a tendency among interpretivists to refer to problems as if they exist separate from interpretive processes, reflected in the languages of "problem setting", "problem structuring", and so on (see above; emphasis added). In this vein, Colebatch (2010: p. 33; emphasis added) declares that policy is a process "driven by a desire to identify and solve problems, and marked by uncertainty and disagreements about the nature of the problems and the effectiveness of the responses to them". Hoppe's (2002: p. 309; emphasis added) typology of kinds of public problems includes as one category, "structured problems", "characterized by high degrees of certain knowledge and consent". Turnbull (2005: p. 269; emphasis added) describes "policy problems" as arising "from the problems of collective life". This fixing of problems and claims to "certain knowledge" would generally be rendered problematic in a poststructural analysis.

Moreover, interpretivists tend to talk about problems in ways that give them a status as negative entities. Hoppe (2011: p. 23), for example, describes a problem as "a gap between a current situation and a more desirable one". For Turnbull a "problem is a worry, or concern" and a policy problem is "something we are concerned about that we refer for collective deliberation" (Turnbull, 2005: p. 238; emphasis added). In Foucault-influenced poststructuralism, by contrast, while it is accepted that troubling conditions may exist, calling them "problems" is held to give those conditions a particular, fixed meaning that needs to be interrogated. To this end scholars working with this perspective create an analytic space to inquire into how the particular issue (the "problem") has been understood and represented (problematized).

For example, the Foucauldian scholar, Rose (2000: p. 58), uses the language of "questions" and "answers" rather than of "problems" and "solutions" to study governing practices ${ }^{6}$. He suggests that we should approach issues such as marketization, imprisonment and community care as answers, and direct attention to the implicit questions that produce such "entities" as answers. In his view this relationship between questions and answers creates the opportunity to inquire into the form of problematization-how the issue is constructed as a "problem"- that produces marketization, for example, as an intelligible answer. Pursuing this line of inquiry, he argues, makes it possible to reflect on the presuppositions and possible limitations in the identified problematization. Attention is directed to entrenched "problematizations" (such as marketization) that potentially limit current thinking about specific issues ${ }^{7}$.

Foucault-influenced poststructuralists, such as Rose, propose the usefulness of identifying patterns of use, which they refer to as "govern-mentalities", in these entrenched problematizations. The suggestion is that governing is facilitated through styles of problematization that affect our lives and impel us to act in particular ways. Dean and Hindess (1998: p. 9), for example, argue that, in a neoliberal "mentality of rule" (or governmentality), individuals are created as "the problem", as the ones responsible for their own health, welfare and economic

\footnotetext{
${ }^{5}$ Hoppe (2011: p. 4) notes the role of "bureaucratic policy staff and science-based experts" in helping governments "translate problems into actionable policies and programmes". While this comment acknowledges the role of groups outside of conventional political institutions in governing, the emphasis remains on the active participation of experts in shaping policies in contrast to Foucault-influenced approaches, which are concerned to highlight the role played in governing practices by expert discourses or knowledges.

${ }^{6}$ The philosopher, Michael Meyer (Turnbull, 2014), treats "problem" and "question" as "equivalent terms" (Turnbull, 2005: p. 231). In his analysis problematizing refers to critical questioning, aligned with the first verb meaning, discussed at the outset, of problematization as critical analysis. For example he refers to answers that close off further questioning as "deproblematising" (Turnbull, 2008: p. 13). Hoppe (2011: p. 4) also, at times, speaks about problems as questions in a "question-and-answer game".

${ }^{7}$ Meyer (see fn 6) also emphasizes that for every answer there is an implicit question. However, he does not look to the forms of problematization that render some "answers" intelligible.
} 
success (see also Turnbull, 2008: p. 23). Hence, they are impelled to assume responsibility for stresses and challenges in their lives, instead of considering how governing practices shape the constraints within which they live and work. In this way, particular styles of problematization make governing possible by producing individuals as "governable subjects", highlighting the importance of identifying and interrogating these "patterns of rule".

This fundamental challenge to governing practices stands in contrast to the declared goal of interpretivists which, as described above, is to assist policy makers/workers to develop a "shared problematization" and to "set problems" within current political arrangements. We turn next to probe more deeply these contrasting political agendas.

\section{Political Agendas}

Researchers in the interpretive tradition have, as their primary objective, training policy makers/workers to "problematize" (to shape problems) in ways described as effective, that is, in a manner that confronts, evaluates and integrates "as much contradictory information as possible" (Hoppe, 2002: p. 321). They promote "the art and craft of policy analysis" (Hoppe, 2011: p. 55). The objective is to endow "forensic policy analysts" with "skills of problem reframing", such as rhetoric and persuasion, in order to "avoid controversies and break deadlocks" (Hoppe, 2002: p. 321). With these skills, it is suggested, policy makers/workers will be better able to manage the diversity of meanings they encounter (Colebatch, 2010: p. 41). There is a clear link here with what is described as the "argumentative turn" in policy analysis (Fischer \& Gottweis, 2012; Hoppe, 2011: p. 173). Through learning how to structure problems (how to problematize), it is argued, policy analysts will be able to "move from inchoate signs of problematic situations, through the unraveling of multiple stakeholders" problem representations, to doable, solvable problems for public policy" and "shared problematization" (Hoppe, 2011: p. 29; Colebatch, Hoppe, \& Noordegraaf, 2010b: p. 236).

The focus on "doable, solvable problems", and continuing references to "problem framing" and "problem definition", illustrate important conceptual connections between current interpretive approaches and earlier "political rationalists" such as Lindblom, Wildavsky and Dery (see Bacchi, 1999: Chapter 1). There are links, for example, between Dery's and Wildavsky's understanding of the place of problems in policy processes on the one hand, and Hoppe's "problem-solution couplings" on the other. Dery (1984: p. 40) offers an "interventionist model" which "requires a problem to be defined in one way only, one that will promote its solution (amelioration or transformation)". Wildavsky (1979: p. 3) concurs: "in public policy... creativity consists of finding a problem about which something can and ought to be done. In a word, the solution is part of defining the problem". This pragmatic view is echoed in Hoppe's (2011: p. 68; emphasis in original) position that, in "moderately structured and unstructured problems", "the problem fits the solution-and not the other way round".

Foucault-influenced poststructuralists have serious qualms about an agenda of creating "doable problems". Rather, their focus is on interrogating existing constructions or representations of "problems" (problematizations) in order to point to possible deleterious consequences that potentially accompany these ways of thinking. As indicated in the previous section on governmentality, the primary target consists of governmental problematizations, with governing understood broadly to refer to the "conduct of conduct".

Bacchi (2009), for example, has produced an analytic strategy that builds on Rose's premise (see above) that we need to initiate our analysis from "answers" or "proposed solutions" and inquire into the problematizations that render these answers intelligible. Her WPR (What's the Problem Represented to be?) approach rests on the simple idea that what we propose to do about something indicates what we think needs to change and, hence, what we think is problematic. Following this line of thought, policies can be seen to contain implicit representations of the "problem" (problem representations) they purport to address ${ }^{8}$. As in Rose, the analytic task is to reflect on the "unexamined ways of thinking" (Foucault, 1994 [1981]: p. 456) in identified problematizations. To this end, the WPR approach offers six questions which together probe the following issues: the conceptual premises underpinning particular problematizations; the contingent practices and processes through which certain representations of the "problem" have gained authenticity and authority; the effects or implications of specific problem representations, including subjectification and lived effects; and the possible benefits of alternatives.

${ }_{8}^{8}$ It is helpful to contrast Bacchi's (2009) concept of problem representation with the reference earlier, in Hoppe (2011: p. 29), to "multiple stakeholders' problem representations". Hoppe here is referring to how stakeholders understand a problem whereas in Bacchi problem representations are located within policies. 
The underlying conviction among Foucault-influenced poststructuralists that governmental problematizations shape who we are and how we live leads Bacchi to build into the WPR approach a practice of self-problematization (see also Webb, 2014). To this end researchers and policy makers/workers are enjoined to seek out possible forms of domination in their own proposals and problematizations by subjecting them to the six questions that make up the approach. Instead of offering "skills" to policy makers/workers to help them shape a "shared problematization", as in the interpretive tradition, Bacchi's poststructural initiative produces ways to interrogate and rethink common forms of problematization in policies and policy proposals, including in one's own proposals.

What implications accompany these distinct perspectives for those involved in policy development?

\section{Policy Design and Political Visions}

Both interpretivism and poststructuralism offer policy makers/workers suggestions for how they might engage in their work and, as Tanesini (1994) anticipated, problematization is defined in terms of their distinct projects. Interpretivists recommend that policy makers/workers become familiar with the tools of "reframing", including rhetoric, narrative and discourse analysis (Colebatch, Hoppe, \& Noordegraaf, 2010b: p. 241), in order to more successfully manage the diversity of views they have to deal with. These tools, it is argued, will assist them to problematize (shape problems) in ways that produce a shared problematization (understanding of the problem) and "doable" problems. Foucault-influenced poststructural policy analysis, by contrast, encourages policy makers/workers to problematize (interrogate) the problematizations (deep-seated conceptualizations of "problems") in the policies and policy proposals they develop and implement. Further, it incorporates a recommendation for a practice of self-problematization.

These contrasting agendas rest on contrary perspectives on the uses of theory. Interpretivists tend to want to use theory to develop interventions and techniques to guide and facilitate reform initiatives. Despite expressed concerns about the excessive focus on "problem-solving" in current governing practices, problem-solving remains a declared objective: "Both problem finding and problem solving are indispensable moments in highquality policy making" (Hoppe, 2011: p. 27). There is a willingness to accept "partial answers" to "complex" problems (Turnbull, 2005: p. 206, 251; Hoppe, 2011: p. 15) in order to "repress unregulated questioning" and to avoid "social disorder" (Turnbull, 2008: p. 27-28). Consensus is seen as a desirable outcome of effective problem management".

For Foucault-influenced poststructuralists, by contrast, the aim of theory is to trouble consensus, which they see as inherently problematic, and to avoid commitment to "problem-solving" tout court. While this position might, at face value, appear to be somewhat perverse (why wouldn't you want to solve problems?), the argument is that problem-solving initiatives invariably accept "problems" as some sort of identifiable ill instead of recognizing them as the effects of political processes. The suggestion, therefore, is to open up existing governmental problematizations to a process of continuous questioning and critique as a move towards contesting problematizations in specific contexts that are deemed to produce possible deleterious consequences.

Interpretivists are not alone in their conviction that the goal of policy theory is to offer advice to policy makers/workers on how to manage problems. Callon (2009: p. 543), for example, one of the initiators of Actor-Network theory, describes problematization as a method for turning broad "issues" into "treatable" problems. The Foucault-influenced scholars Rabinow (2012) and Koopman (2013) also support a pragmatic orientation in policy analysis. Koopman (2013: p. 139), in fact, makes a case that Foucault had a pragmatist tinge, that he often took up experimentation "as a model of reconstructive problem-solving", a view that requires further discussion given its distance from the position on Foucault developed in this paper ${ }^{10}$.

\footnotetext{
${ }^{9}$ Fairclough \& Fairclough (2012) have produced a version of Critical Discourse Analysis that incorporates argumentation theory (see Fairclough, 2013: p. 177-178). However, Norman Fairclough expresses qualms concerning some analyses-his example is Fischer (2003) - that associate an argumentative focus with a "search for consensus" (Fairclough, 2013: p. 193). Fairclough also takes issue with the ways in which some poststructural researchers create a link between problems and solutions. Fairclough (2013: p. 185) declares himself committed to "(critical) realism" and a "moderate constructivism", in which the point of critique is to ask "what the problems really are". Problematizations, in his account, represent the views of various groups of social actors about the nature of those problems. This understanding of problematization is similar both to interpretivism (despite the disagreement about consensus) and to the version of poststructuralism in Glynos and Howarth (2007; see above). It sits at some distance from the focus in Foucault-influenced poststructuralism on the implicit problematizations within policies and policy proposals.

${ }^{10}$ For a critique of Koopman's argument, see Thompson (2010).
} 
While Koopman (2013: p. 3) is sensitive to Foucault's project, which he describes as "this great problem of who we are and who we can be", he fails to take on board Foucault's "purgative practice of historical nominalism" (Flynn, 2005: p. x). For Foucault "madness" and "sexuality" are problematized objects for thought, produced in practices-no more, no less (see above). Hence, the critical task becomes considering how these "entities" emerge in practices as "problems", not to assign a problem status to them, as Koopman (2013: p. 3) tends to do. This tendency to affix meanings to "entities" such as sexuality is necessary to Koopman's argument that Foucault intended to give us the tools to "specify the details of a problematic situation" and to assist us "to appropriately perceive problems" (Koopman, 2013: p. 247; emphasis added). In the process, Foucault's insistence on the importance of problematization, "perpetual reproblematization" and self-problematization-problematizing "even what we are ourselves" (Foucault, 1984b: p. 1431; emphasis added)-tends to get lost. So too does Foucault's commitment to a "philosophical ethos" as "a permanent critique of our historical era" (Foucault 1984a: p. 42; emphasis added).

As part of the practice of "permanent critique", it is possible to reflect on the complex array of implications that problematizations entail in specific contexts and to modify interventions in ways that reduce deleterious consequences ${ }^{11}$. However, this kind of intercession does not make problematization a "diagnostic" tool to assist the pragmatist "to articulate and innovate practices that promise a resolution of the problematic situation" (Koopman, 2013: p. 225; 2011: p. 7; emphasis added). There is no attempt to seek "solutions" to "problems" because there is no presumption that a problem exists ${ }^{12}$. Moreover, any proposal for change becomes subject to self- problematization, as in the undertaking in the WPR approach to apply the six questions to one's own proposals (Bacchi, 2009: p. 19).

\section{Conclusion}

Both interpretive and poststructural approaches cultivate new thinking about how policy is done and encourage practitioners to challenge technocratic styles of policy development. There is also a shared concern about finding ways to engage and critique dominant "problem definitions" (Hoppe, 2011: p. 49) or pervasive "problem representations" (Bacchi, 2009). The different languages here mark the distance between the two approaches. "Problem definitions" are seen as negotiated interpretations that sit outside of problems that exist. By contrast, problem representations are the ways in which particular policy "problems" are constituted in the real (Bacchi, 2009: p. 35). In addition, whereas interpretive and some poststructural approaches work through the self-understandings of political subjects (Glynos \& Howarth, 2007; see above), Foucault-influenced poststructural approaches offer strategies, including a practice of self-problematization, to help us to think about how we become the people we are.

In the end the two analytic traditions-interpretivism and Foucault-influenced poststructuralism-line up with divergent political projects. An interpretive view of problematizations as competing understandings of problems, together with the conviction that the goal of the analyst is to train policy makers/workers in problematizing skills, supports a reformist agenda. By contrast, the study, in Foucault-influenced poststructural accounts, of problematizations as deep-seated conceptual schema that shape lives, offers a more thoroughgoing analysis of how we are governed, a level of analysis that prefers "unregulated questioning" to "partial answers" (Turnbull, 2005: p. 206, 251; Turnbull, 2008: p. 27-28).

Interpretivists turn their attention to assisting policy workers to learn how to problematize (to shape understandings of problems) in order to negotiate shared problematizations (interpretations of problems) that will enable a reform agenda. Foucault-influenced poststructuralists, by contrast, recommend that we all (i.e. researchers, policy makers/workers, etc.) engage in problematizing (critically interrogating) existing problematizations (deep-seated conceptualizations of "problems" in policies and policy proposals), including our own problematizations. Whereas the former aims to produce "doable problems", the latter recommends a process of continuous critique.

These reflections have implications for political theory more generally, specifically for Shapiro's (2002) widely endorsed "problem-driven research" (Glynos \& Howarth, 2007: p. 167; Fairclough, 2013: p. 185). Glynos and Howarth (2007: p. 84) are concerned by Shapiro's critical realism yet they quote him to support, as a

\footnotetext{
${ }^{11}$ See Question 5 in Bacchi's (2009) WPR approach to policy analysis.

${ }^{12}$ There is slippage in Koopman around the term "problem". While he makes the point that the nature of a problem is ambiguous and open to contestation, at times he (2013: p. 147) refers to problems as if they are incontrovertible.
} 
project, to "illuminate a problem that is specified independently" of a particular theory ${ }^{13}$. Glynos, Howarth and others in the Essex School of Discourse Analysis (Glynos et al., 2009: p. 6; emphasis in original) state that they take "problem-drivenness as a basic starting point" for "inter-approach conversations", and wish to refocus the debate "around common problem areas". No specification is offered of what is meant in these references to "problems" or how "problem areas" are to be identified. Given the ambiguity around the meaning of the term "problem"- whether it signals a concern, a gap between the current situation and a more desired state (Hoppe, 2011: p. 23), or simply a question-perhaps it is time to leave the commonly used and vague notion of problem out of political theory altogether and to institute problematization-driven analysis (Alvesson \& Sandberg, 2011). As we have seen, however, recalling Tanesini's (1994: p. 207) proposition that concepts are "proposals about how we ought to proceed from here", this initiative would need to be accompanied by robust discussion about the political visions that underpin our uses of the term. This paper initiates this discussion.

\section{Acknowledgements}

The author would like to thank Anne Wilson for comments on this and earlier drafts of the paper.

\section{References}

Alvesson, M., \& Sandberg, J. (2011). Generating Research Questions through Problematization. Academy of Management Review, 36, 247-271. http://dx.doi.org/10.5465/AMR.2011.59330882

Alvesson, M., \& Sandberg, J. (2013). Constructing Research Questions: Doing Interesting Research. London: Sage.

Bacchi, C. (1999). Women, Policy and Politics: The Construction of Policy Problems. London: Sage.

Bacchi, C. (2009). Analysing Policy: What's the Problem Represented to Be? Frenchs Forest, NSW: Pearson Education.

Bacchi, C. (2012). Why Study Problematization? Making Politics Visible. Open Journal of Political Science, 2, 1-8. http://dx.doi.org/10.4236/ojps.2012.21001

Bacchi, C., \& Rönnblom, M. (2014). Feminist Discursive Institutionalism-A Poststructural Alternative. NORA-Nordic Journal of Feminist and Gender Research, 22, 170-186. http://dx.doi.org/10.1080/08038740.2013.864701

Burr, V. (2003). Social Constructionism (2nd ed.). London: Routledge.

Callon, M. (2009). Civilizing Markets: Carbon Trading between in Vitro and in Vivo Experiments. Accounting, Organization and Society, 34, 535-548. http://dx.doi.org/10.1016/j.aos.2008.04.003

Colebatch, H. (2010). Giving Accounts of Policy. In H. Colebatch, R. Hoppe, \& M. Noordegraaf (Eds.), Working for Policy (pp. 31-43). Amsterdam: Amsterdam University Press. http://dx.doi.org/10.5117/9789089642530

Colebatch, H., Hoppe, R., \& Noordegraaf, M. (2010a). Preface. In H. Colebatch, R. Hoppe, \& M. Noordegraaf (Eds.), Working for Policy (pp. 8-9). Amsterdam: Amsterdam University Press.

Colebatch, H., Hoppe, R., \& Noordegraaf, M. (2010b). The Lessons for Policy Work. In H. Colebatch, R. Hoppe, \& M. Noordegraaf (Eds.), Working for Policy (pp. 227-245). Amsterdam: Amsterdam University Press.

Colebatch, H., Hoppe, R., \& Noordegraaf, M. (Eds.). (2010). Working for Policy. Amsterdam: Amsterdam University Press. http://dx.doi.org/10.5117/9789089642530

Dean, M., \& Hindess, B. (1998). Governing Australia: Studies in Contemporary Rationalities of Government. Cambridge: Cambridge University Press.

Dery, D. (1984). Problem Definition in Policy Analysis. Lawrence, KS: University Press of Kansas.

Eribon, D. (1991). Michel Foucault. London: Faber and Faber.

Fairclough, I., \& Fairclough, N. (2012). Political Discourse Analysis: A Method for Advanced Students. London: Routledge.

Fairclough, N. (2013). Critical Discourse Analysis and Critical Policy Studies. Critical Policy Studies, 7, 177-197. http://dx.doi.org/10.1080/19460171.2013.798239

Fischer, F. (2003). Reframing Public Policy: Discursive Politics and Deliberative Practices. Oxford: Oxford University Press. http://dx.doi.org/10.1093/019924264X.001.0001

Fischer, F., \& Gottweis, H. (Eds.) (2012). The Argumentative Turn Revisited: Public Policy as Communicative Practice. Durham: Duke University Press. http://dx.doi.org/10.1215/9780822395362

\footnotetext{
${ }^{13}$ In context Shapiro (2002: p. 601) offers this critique of what he describes as theory-driven research: “... if a phenomenon is characterized so as to vindicate a particular theory rather than to illuminate a problem that is specified independently of the theory, then it is unlikely that the specification will gain much purchase on what is actually going on in the world."
} 
Fischer, F., \& Mandell, A. (2012). Transformative Learning in Planning and Policy Deliberation: Probing Social Meaning and Tacit Assumptions. In F. Fischer, \& H. Gottweis (Eds.), The Argumentative Turn Revisited: Public Policy as Communicative Practice (pp. 343-370). Durham: Duke University Press.

Flynn, T. (2005). Sartre, Foucault, and Historical Reason: A Poststructuralist Mapping of History Vol. II. Chicago, IL: University of Chicago Press. http://dx.doi.org/10.7208/chicago/9780226254722.001.0001

Foucault, M. (1969). Pamphlet Submitted to Professors of the Collège de France. Cited in D. Eribon (1991) Michel Foucault (pp. 214-216). B. Wing (Trans.), Cambridge, MA: Harvard University Press.

Foucault, M. (1984a). What Is Enlightenment? In P. Rabinow (Ed.), The Foucault Reader (pp. 32-50). New York: Pantheon Books.

Foucault, M. (1984b). A propos de la généalogie de l'éthique: Un apercu du travail en cours (Rewritten Version). Dits et Ecrits. Tome II (1994) (pp. 1428-1450). Paris: Gallimard.

Foucault, M. (1986). The Use of Pleasure: The History of Sexuality Vol. II. New York: Vintage.

Foucault, M. (1994) [1981]. So Is It Important to Think? In J. D. Faubion (Ed.), Power: Essential Works of Foucault 1954-1984 (Vol. 3, pp. 454-458). Trans. R. Hurley and Others, London: Penguin.

Foucault, M. (2009). History of Madness. Trans. J. Khalfa. New York: Routledge.

Freire, P. (1970). Pedagogy of the Oppressed. New York: Seabury.

Freire, P. (1973). Education for Critical Consciousness. New York: Seabury.

Glynos, J., \& Howarth, D. (2007). Logics of Critical Explanation in Social and Political Theory. London: Routledge.

Glynos, J., Howarth, D., Norval, A., \& Speed, E. (2009). Discourse Analysis: Varieties and Methods. Colchester: Centre for Theoretical Studies in the Humanities and Social Sciences, University of Essex. ESRC National Centre for Research Methods; NCRM/014.

Gordon, C. (1991). Governmental rationality: An introduction. In G. Burchell, C. Gordon, \& P. Miller (Eds.), The Foucault Effect: Studies in Governmentality (pp. 1-52). Chicago, IL: University of Chicago Press.

Hoppe, R. (1999). Policy Analysis, Science, and Politics: From "Speaking Truth to Power" to "Making Sense Together". Science and Public Policy, 26, 201-210. http://dx.doi.org/10.3152/147154399781782482

Hoppe, R. (2002). Cultures of Public Policy Problems. Journal of Comparative Policy Analysis: Research and Practice, 4 , 305-326. http://dx.doi.org/10.1080/13876980208412685

Hoppe, R. (2011). The Governance of Problems: Puzzling, Power and Participation. Bristol: Policy Press.

Howarth, D. (2013). Poststructuralism and After: Structure, Subjectivity and Power. Houndmills: Palgrave. http://dx.doi.org/10.1057/9781137266989

Howarth, D., \& Griggs, S. (2012). Poststructuralist Policy Analysis: Discourse, Hegemony, and Critical Explanation. In F. Fischer, \& H. Gottweis (Eds.), The Argumentative Turn Revisited: Public Policy as Communicative Practice (pp. 305342). Durham: Duke University Press.

Howarth, D., Norval, A., \& Stavrakakis, Y. (Eds.) (2000). Discourse Theory and Political Analysis. Manchester: Manchester University Press.

Jones, A. (1997). Teaching Post-Structuralist Feminist Theory in Education: Student Resistances. Gender and Education, 9 , 261-269. http://dx.doi.org/10.1080/09540259721240

Koopman, C. (2011). Foucault and Pragmatism: Introductory Notes on Metaphilosophical Methodology. Foucault Studies, $11,2-10$

Koopman, C. (2013). Genealogy as Critique: Foucault and the Problems of Modernity. Bloomington, IN: Indiana University Press.

Osborne, T. (1997). On Health and Statecraft. In A. Petersen, \& R. Bunton (Eds.), Foucault, Health and Medicine (pp. 173-188). London: Routledge.

Rabinow, P. (2012). How to Submit to Inquiry: Dewey and Foucault. The Pluralist, 7, 25-37. http://dx.doi.org/10.5406/pluralist.7.3.0025

Rose, N. (2000). Powers of Freedom: Reframing Political Thought (1st ed., 1999). Cambridge: Cambridge University Press.

Rose, N., \& Miller, P. (1992). Political Power beyond the State: Problematics of Government. The British Journal of Sociology, 43, 173-205.

http://links.jstor.org/sici?sici=00071315\%28199206\%2943\%3A2\%3C173\%3APPBTSP\%3E2.0.CO\%3B2-Y

http://dx.doi.org/10.2307/591464

Schön, D. A. (1983). The Reflexive Practitioner: How Professionals Think in Action. New York: Basic.

Shapiro, I. (2002). Problems, Methods, and Theories in the Study of Politics, or What's Wrong with Political Science and 
What to Do about It. Political Theory, 30, 596-619. http://www.jstor.org/stable/3072623 http://dx.doi.org/10.1177/0090591702030004008

Tanesini, A. (1994). Whose Language? In K. Lennon, \& M. Whitford (Eds.), Knowing the Difference: Feminist Perspectives in Epistemology (pp. 203-216). New York: Routledge. http://dx.doi.org/10.4324/9780203216125 chapter 13

Thompson, K. (2010). Response to Colin Koopman's "Historical Critique or Transcendental Critique in Foucault: Two Kantian Lineages". Foucault Studies, 8, 122-128.

Turnbull, N. (2005). Policy in Question: From Problem Solving to Problematology. Sydney: University of New South Wales.

Turnbull, N. (2006). How Should We Theorize Public Policy? Problem Solving and Problematicity. Policy and Society, 25, 3-22. http://dx.doi.org/10.1016/S1449-4035(06)70072-8

Turnbull, N. (2007). Introduction: Problematology: A New Paradigm for Thought. Revue internationale de philosophie, 4, 349-352.

Turnbull, N. (2008). Legitimation in Terms of Questioning: Integrating Political Rhetoric and Sociology of Law. Workshop on Normative and Sociological Approaches to Legality and Legitimacy, Oñati, 24-25 April 2008, 1-29. www.dcern.org.uk/documents/TurnbullLegitimation.pdf

Turnbull, N. (2014). Michael Meyer's Problematology: Questioning and Society. London: Bloomsbury.

Webb, P. T. (2014). Policy Problematization. International Journal of Qualitative Studies in Education, 27, 364-376. http://dx.doi.org/10.1080/09518398.2012.762480

Weedon, C. (1987). Feminist Practice and Post-Structuralist Theory. Oxford: Basil Blackwell.

Wildavsky, A. (1979). The Art and Craft of Policy Analysis. London: Macmillan. 
Scientific Research Publishing (SCIRP) is one of the largest Open Access journal publishers. It is currently publishing more than 200 open access, online, peer-reviewed journals covering a wide range of academic disciplines. SCIRP serves the worldwide academic communities and contributes to the progress and application of science with its publication.

Other selected journals from SCIRP are listed as below. Submit your manuscript to us via either submit@scirp.org or Online Submission Portal.
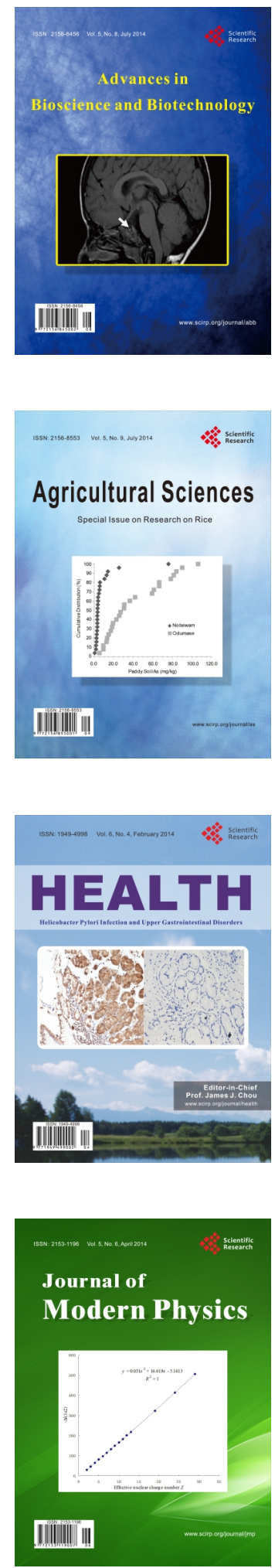
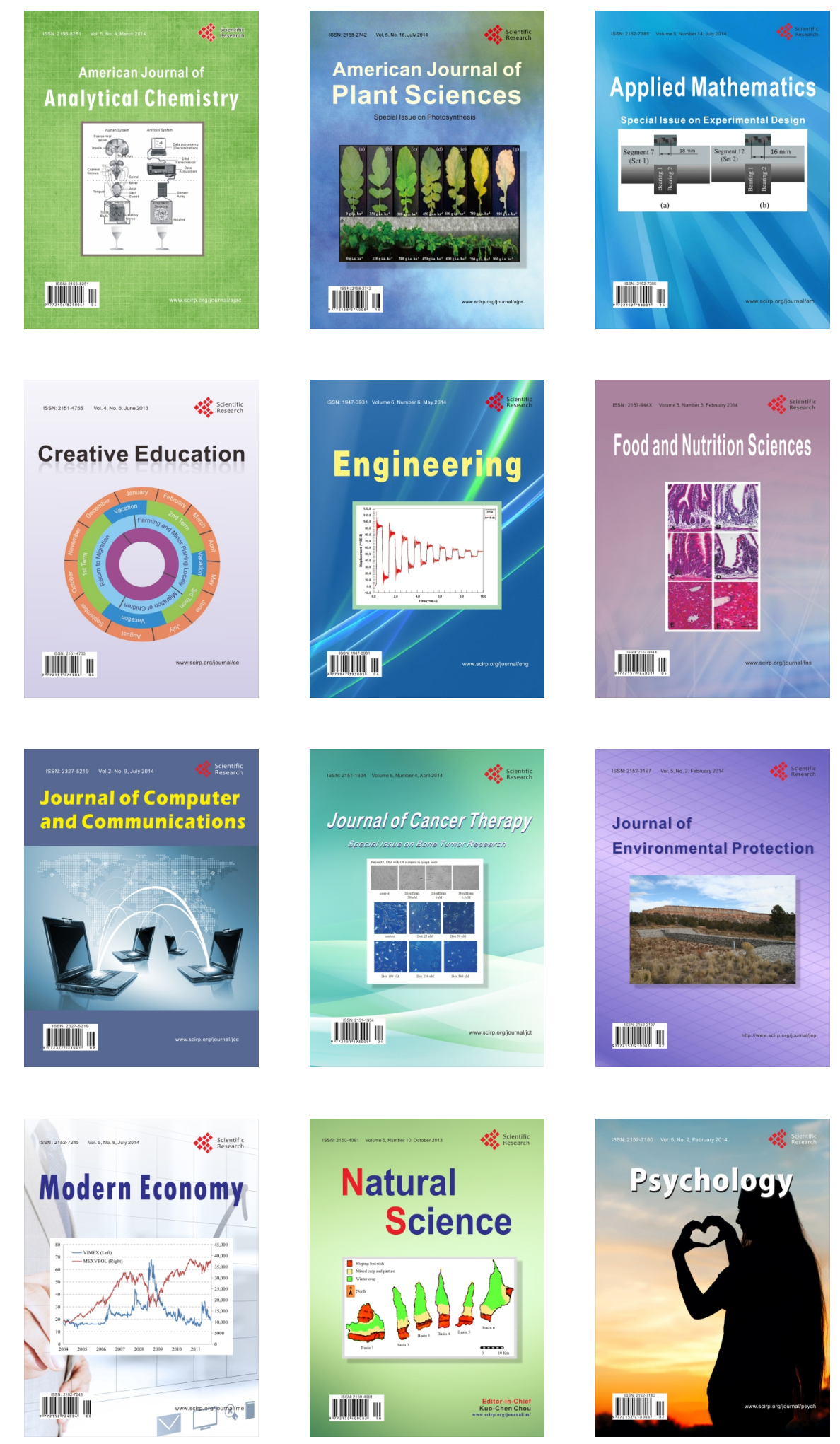